Marquette University

e-Publications@Marquette

Philosophy Faculty Research and Publications

Philosophy, Department of

3-1-1993

Parmenides on Possibility and Thought

Owen Goldin

Marquette University, owen.goldin@marquette.edu

Published version. Apeiron, Vol. 26, No. 1 (March 1993): 19-35. Permalink. (C) 1993 Walter de Gruyter. Used with permission. 


\section{Parmenides on Possibility and Thought}

Owen Goldin

Given the evidence and the nature of Parmenides' writing, it seems that Mourelatos $(1979,5)$ is right in his suggestion that it is time for a 'tolerant pluralism' in Parmenidean scholarship. But if a definitive interpretation is beyond our reach, we may yet make progress in understanding what is to be gained or lost in the depth, cogency, and clarity of our interpretation of the whole poem when we interpret a line or an argument in one manner rather than another.

For this reason, I do not here defend a complete interpretation of what remains of Parmenides' poem. In most important respects I pursue the interpretive path taken by G.E.L. Owen (1987a) in his highly influential interpretation of the poem. But I take issue with Owen's claim that Parmenides' argument for the existence of any object of reference or thought rests on fallacious modal logic. I also take issue with the view of Tugwell (1964) that Parmenides' argument rests on a naive and philosophically unsatisfactory blurring of the distinction between the potential and existential uses of Eîvol. I suggest that Parmenides' argument for the being of the object of thought and speech takes a different course. On my view, Parmenides explicitly denies that there are unreal but possible things or states of affairs, on the grounds that possible beings can be understood only as beings and hence as real. Since any object of thought or speech is a possible thing or state of affairs, any object of thought or speech is. On my view, Parmenides thus draws attention to what has come to be a perennial metaphysical problem: what status is to be given to possible beings?

I begin by sketching a key part of Owen's interpretation of Parmenides' poem. Parmenides wishes to indicate what can be said of any 
object of thought or speech; the attributes and identity of such a thing are meant to become clear in the inexorable course of the poem's deductions (Owen 1987a, 14-16). In fr. 2, Parmenides indicates two paths for thought, one to be taken, one to be avoided at all costs. The first is 'that it exists and that it is not possible for it not to exist' (i.e., that it necessarily exists), the second that it does not exist and it necessarily does not exist. ${ }^{1}$ These paths, which present the directions in which thought can proceed, are taken to be expressed as propositions, premises from which there are to be deduced further propositions, for example, that it is one and that it neither comes to be nor passes away (Owen 1987a13-14, 1987b, 33). But these premises are themselves not axiomatic. Nor are they implicitly supported on Meinongian grounds (that is, on the basis of the argument that an object of thought must be, at least qua object of thought). ${ }^{2}$ Rather there is an explicit argument for these prem-

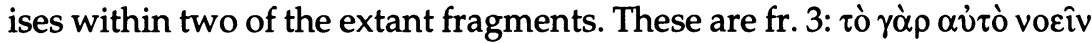

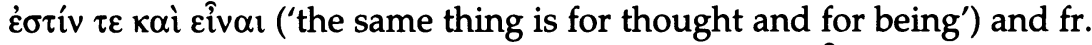

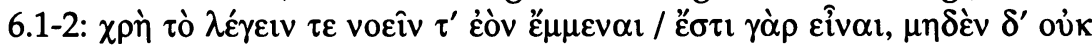

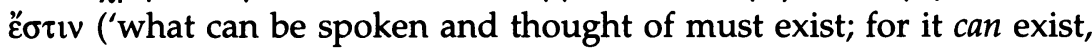
whereas nothing cannot'), following which the presence of an argument is signaled by the imperative 'think that out' (fr. 6.2) (Owen 1987a, 15).

1 The interpretation of Owen, as well as that of Barnes, rests on taking certain occurrences of eival to have the verb's existential sense. Furth (1968) has argued that within Parmenides' poem, عiv $\alpha$ l has a 'fused' sense, according to which the verb simultaneously has what we distinguish as its existential, predicative, and veridical senses. Furth's strategy in his paper is to show how the semantic complexity of eiv $\alpha \mathrm{l}$ allows us to understand Parmenides as presenting concurrent arguments concerning what exists, what is something or other, and what is true. I concur. The interpretation $I$ here propose can hold if the relevant occurrences of eiv $\alpha_{l}$ are given existential, predicative, or veridical senses. (However, those instances of eiv $\alpha_{1}$ I understand as 'potential-existential,' namely the ciol at fr. 2, 2, the हैo $\tau$ at fr. 2, 3, the

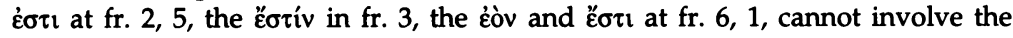
predicative or veridical senses in a way consistent with my understanding of their grammatical roles.) See notes 7,11, and 17. But for the sake of simplicity, within the main text I take Owen's interpretation as a point of departure and take eiv $\alpha \mathrm{l}$, in the occurrences in question, to have its existential sense.

2 Such an interpretation is presented by Hussey $(1972,85-6)$. On this interpretation, Parmenides is taken to be making the kind of Meinongian inference that we find at Republic V 478B-C: what is an object of thought must be, insofar as it is an object of thought. 
The argument, as reconstructed by Owen (1987a, 15-16) and followed in its essentials by Barnes $(1982,164-7,174-5)^{3}$ is as follows. What can be thought can be, and what can be can be thought. But what is not cannot be. Since it is not the case that what is not can be, it is not the case that what is not can be thought. Hence if something is an object of thought, it cannot be what is not; by logical necessity ${ }^{4}$ it is what is. This logical

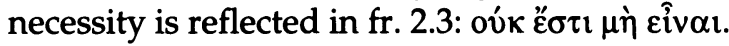

On this interpretation, Parmenides asserts that what is not cannot be

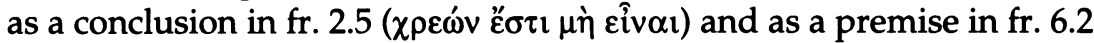

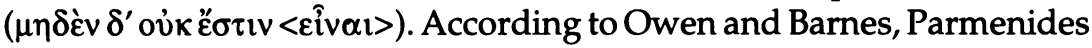
has no warrant in taking the necessity here as $d e$ re; on what grounds could Parmenides take all cases of nonbeing to be necessary de re? To say this would be to glibly assert that possible being and actual being are coextensive. This runs counter to both language and metaphysical intuition. We often conceive and talk about nonbeings that might have been. Parmenides is justified in saying only that, from the fact that something is not, it follows as a matter of logical necessity that it is not. ${ }^{5}$ But the conclusion 'what is not cannot be an object of thought' follows only if 'what is not cannot be' is taken to assert that, for any nonbeing, the fact that it is not is necessary de re, that is, its nonbeing is a necessary feature of reality. ${ }^{6}$ So Parmenides' argument rests on the confusion between necessitas consequentis and necessitas consequentiae (Owen 1987a, 15n47, Barnes 1982, 164).

One may on philosophical grounds challenge whether we are justified in imputing to Parmenides the fallacious argument outlined above. Further, there is a philological challenge to the Diels-Kranz reading of fr. 6,1 , on which the Owen/Barnes interpretation rests. I first indicate

3 On this see also Anscombe (1968/9, 125-6).

4 I follow Sorabji $(1980,206)$ in my use of 'logical necessity' here: 'We take a logically necessary truth as one which is forced on us by the meanings of the logical particles alone ('not', 'if', 'then', 'and', etc.)' Logical necessity so understood is a kind of de dicto necessity. The logical necessity of fr. 2.3 is that of the conditional.

5 This is symbolized: $\square(\sim p \rightarrow \sim p)$, where $p$ is an assertion of being, in whatever sense we take to be Parmenides' concern. This would then make a statement of de dicto or logical necessity.

6 This is symbolized: $\sim p \rightarrow \square \sim p$. Here we make a statement of de re or metaphysical necessity. 
the objections, and then suggest a line of interpretation that maintains the general drift of Owen's understanding of the poem, meets both the philosophical and philological objections, and has Parmenides making a philosophically significant point concerning the metaphysics of possible being.

Ibegin with the philosophical objection. In response to Owen's analysis, Tugwell has written that Parmenides has erred in holding that

if a thing is thinkable it must exist. This is not a mere petitio principii; it arises in part from the ambiguous nature of the word Eival. If you can

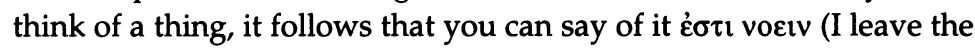
words unaccented intentionally). It is unfair to translate this, "it is possible for it to be thought about." This separates off the potential Eî $\alpha_{l}$ from the existential to an anachronistic extent ... I should prefer

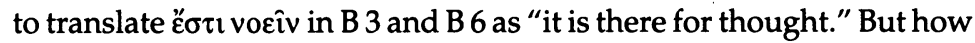
can it be there for thought if it is not there? $(1964,36-7)$

Tugwell suggests that civol is ambiguous, and Parmenides simply did not have a sufficient semantic analysis of the term to allow him to avoid confusion in his argument. On this reading, Parmenides would reason for the necessary being of any object of reference or thought as

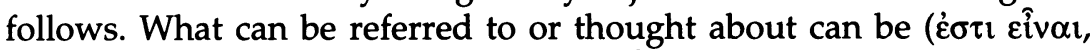
where $\dot{\varepsilon} \sigma \tau \imath$ has its potential sense and عîv $\alpha \iota$ has its existential sense).

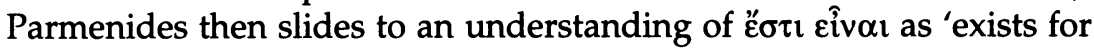
being', where both verbs have the existential sense, and the second is an example of the dative or explicative infinitive. This yields the conclusion that necessarily, what can be referred to or thought exists. ${ }^{7}$ It follows that what does not exist can neither be referred to nor be thought. ${ }^{8}$

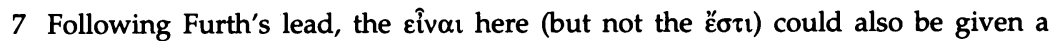
predicative or veridical sense. On this account, Parmenides slides from under-

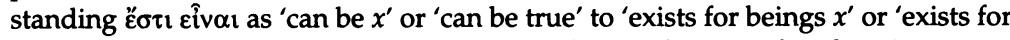
being true.' It follows that what can be $x$, or what can be true, already exists.

8 Tugwell may not be entirely consistent in his account of Parmenides' argument. He translates 6.1 as 'what exists to be referred to or thought about, must exist; for it is there to exist' but paraphrases this as 'if you are thinking about something ... if it is nothing, it cannot (presumably logical necessity here) be something, and so it cannot be what you were thinking about' $(1964,2)$. Here Parmenides is not taken to be discussing what can be thought about (which is what is required for determining 
On this interpretation, then, Parmenides' fallacy is taken to lie not in the misplacement of modal qualifiers but in his ignorance of how his language is equivocal.

Kahn's ground breaking studies on îv $\alpha l(1966,1973)$ provide partial confirmation of Tugwell's remarks. Kahn showed that Eiv $\alpha \mathrm{l}$ as a verb of occurrence, in which an abstract verbal noun is the subject of eiv $\alpha 1$, is developed from the locative sense of eiv $\alpha 1$, in which it is said that there is something of a certain kind at some place. ${ }^{9}$ When the infinitive is employed instead of the verbal noun, the infinitive denotes an action not 'as fact but as a goal or project to be carried out.' In "H

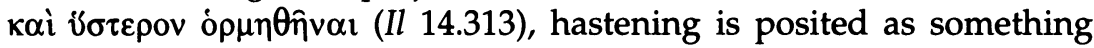
available as intention or goal. This is the root sense of the potential use of عival, in which it 'functions as a (modal) sentence operator on the underlying sentence represented by the infinitival clause' (1973, 295-6, cf. 1968/9, 709-10n.12).

Kahn's more detailed analysis shows that Tugwell was right in denying that the ancient Greek mind would have discerned a sharp distinction between the potential and existential (or locative) uses of $\varepsilon \hat{i v} \alpha \mathrm{l}$. Since Owen's analysis rested on there being a firm distinction between these two senses, it needs to be amended in light of these results.

There is another respect in which recent research has shown that Owen's analysis needs to be amended. As we have seen, Owen accepts the

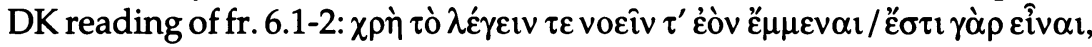

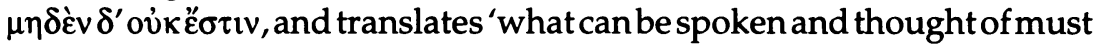
exist, for it can exist, whereas nothing cannot. As so rendered, fr. 6.1 provides the theoretical justification for taking the first path of inquiry and for shunning the second, while fr. 6.2, along with fr. 3, provides the argument for this. Since it was first proposed by Burnet $(1930,174)$, the viability of this reading of the Greek has been the object of a long and sustained controversy (see e.g. Kahn 1968/9,722n26). But the point is now moot, since Cordero has reported the results of Taran's examination of the manuscripts: Diels erred in indicating $\tau \varepsilon$ instead of $\tau$ ò as the manuscript

the path for inquiry) but is taken to be discussing what is thought at a given time. So Tugwell at this point interprets Parmenides to be arguing along Meinongian lines.

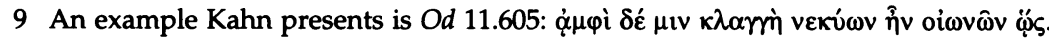
Here an action, considered as actual, is said to be occurring at a place $(1973,283)$. 


\section{Owen Goldin}

reading (Cordero 1979, 24-25n1; 1987, 19-20). So while Owen took the

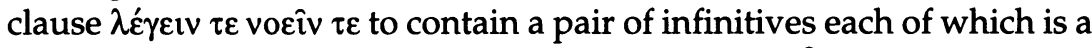
complement of the participial form of the potential eîv $\alpha_{\imath}$ ( $\tau$ ò ... Ėòv), we now see that the first $\tau \varepsilon$ must be read as a $\tau$. How are we to construe this second $\tau$ ò, and still preserve the sense advocated by Owen? It cannot modify żòv; that is the task of the first $\tau$ ó. Nor can it modify either infinitive,

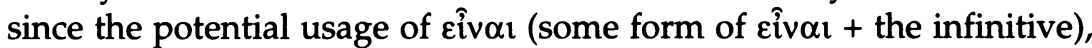
which must be seen to be employed here if the clause is to have the sense advocated by Owen, does without the definite article. So a crucial prop of Owen's interpretation of the argument is removed.

Let us see if we can reconstruct Parmenides' argument, with the above

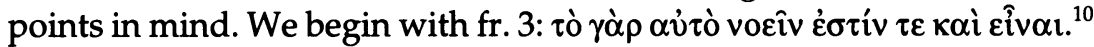

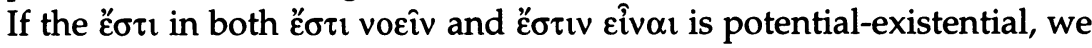
must understand Parmenides as saying that it is the same thing whose being ${ }^{11}$ is present as a project, goal, or intended activity and of which the cognition is likewise present (at least) as a project, goal or intended activity. If a goal or plan is available for action, it is at least available for cognition, and vice versa.

This analysis has both advantages and disadvantages. One advantage is that it allows us to interpret fr. 3 as providing the premise 'that which can be thought can be'. Another advantage is that it does not rest on taking

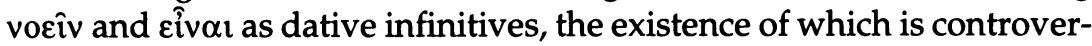

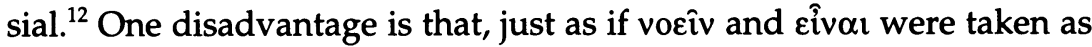

10 Kahn himself $(1968 / 9,721)$ translates fr. 3 as 'for knowing and thinking are the same,' departing from most English language commentators since Burnet. He likewise gives 6.1-2 a (nowadays) unorthodox rendering according to which it too affirms an identity between being and thought: 'Cognition and statement must be what-is (i.e., must be true and real)' $(1968 / 9,722)$. He does not, however, show how, on this interpretation, these lines would not be out of place within the context of the rest of fr. 6. Though I am here using Kahn's analysis of eivaı to shed light on fragments 3 and 6, my understanding of these fragments is very different from that of Kahn.

11 'Being' here can be taken as existential, or in the 'fused' sense proposed by Furth, on which see $n .1$.

12 See Kahn $(1973,179$ n108). In spite of Kahn's objections, it is still the common practice to render these and other infinitives in the poem as dative infinitives. Indeed Kahn himself interprets voñ $\alpha_{\mathrm{l}}$ at fr. 2.2 as 'loosely epexegetical' though he parts from most scholars in taking it to be a complement of ó $\delta i^{\prime}(1968 / 9,703 n 4)$. It is hard to 


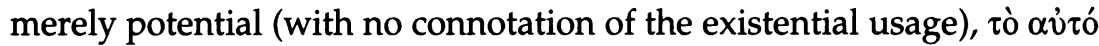
functions as both the object of vokiv and the subject of eivval. Though this reading is somewhat awkward, this is not a decisive objection, since there are examples of similar constructions employed by other writers. ${ }^{13} \mathrm{~A}$ second disadvantage is that, in order to yield the desired premise, that what is capable of being thought is capable of existing, that which है $\sigma \tau \imath$ Eiv $\alpha l$ cannot be restricted to those activities or entities which are the objects of intention or purpose. To this two responses can be made. First, Aristotle, whose metaphysics of nature was intended to support and render intelligible an everyday understanding of the world, held that realizations of possibilities were attainments of goals, even if these realizations were not goals held by conscious agents. It may not have been so alien to the Greek mind to take every case of possible being as having the status of something aimed at or intended. Second, Kahn's analysis is intended to elucidate 'the uses of the verb before it became a topic for philosophical discussion' and 'the ontological predispositions of the Greek language, and not with the philosophic doctrines that exploit these linguistic possibilities' $(1973,9)$. Parmenides may well have been on the way to a technical refinement of the potential civoul; perhaps for him it no longer denotes having some location in its availability for human action. The important point is that it still maintains the sense of having a location

understand this 'epexegetical' infinitive in a way other than as functioning as a dative, even if it is here a dative complement of a noun and not a verb. It would

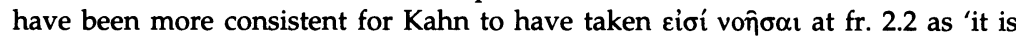
possible to think,' explicated in accordance with his understanding of the potential Eiv $\alpha$. The objection Kahn raises, that for Parmenides the second way cannot be thought, is answered by Furth (1968, 131-32): 'Parmenides' basic procedure is elenctic.' But it should be noted that my remarks on the metaphysical import of frs. 3 and 6 would hold even if the 'Eival + the infinitive of $x^{\prime}$ construction in these fragments were to be taken as 'is for $x$-ing,' with the infinitive playing the role of a dative (thereby avoiding the second of the two disadvantages of my proposed interpretation that I have indicated below). For the subject of Eiv $\alpha \iota$ would be already posited as something that is.

13 For the objection see Mansfeld $(1964,63-4)$. For a response, see O'Brien $(1987,20)$,

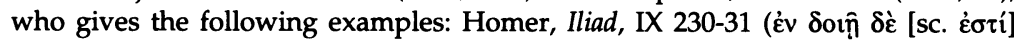

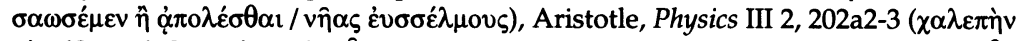

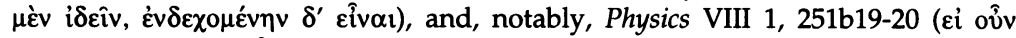

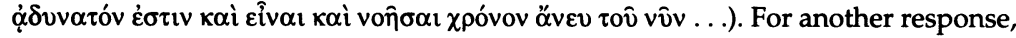
see Furley $(1969,11 n 35)$. 


\section{Owen Goldin}

through some kind of availability. Inasmuch as it has such a location, that which is denoted by the infinitive in the $\varepsilon i v \alpha \imath+$ infinitive construction in some sense already is. ${ }^{14}$

So we follow Owen in interpreting fr. 3 as affirming that possible objects of thought and possible beings are coextensive. We differ in seeing that, in employing the potential cîv $\alpha$, Parmenides already signals that what is possible has the status of presence as available.

Let us consider the status of Parmenides' argument once fr. 3 has been posited. If we take it as an initial assumption that there are three classes ${ }^{15}$ a) what is, b) what can be but is not, and c) what cannot be and (consequently) is not, fr. 3 yields the result that only members of classes $a$ and $b$ are possible objects of thought. But the conclusion of fr. 2 is not that thought (and consequently speech) are to be restricted to possible beings, but that they are to be restricted to what (really) is (class a). So it must be shown that class $b$ is empty. I suggest that fr. 6, 1-2 (on the reading of the manuscript), the context of which is unknown, provides an argument for precisely this conclusion: that everything that can be is.

The fact that some things are unreal yet possible is an obvious objection to Parmenides, and one that clearly does not depend on the formulation of later philosophical innovations. ${ }^{16}$ It would have been strange for Par-

14 Cf. Kahn (1966, 258): 'We have from Presocratic times the well-established axiom that whatever is, is somewhere; what is nowhere is nothing.'

15 I use the term 'class' here in a loose sense, as signifying kinds conceivable in this dialectical context.

16 So, in the context of an evaluation of Parmenides' argument as he conceives of it, Barnes $(1982,167)$ raises the objection 'Not all nonentities are impossibilia: many things might, but do not exist,' and calls the flaw in the argument 'obvious and ... offensive.' Owen (1987a, 11n34) takes Parmenides to implicitly acknowledge the objection insofar as Parmenides grants the possibility of a third way of inquiry, which is attained through negating both of the first two ways, so that the object of the third way of inquiry is such that it is possible to be and it is possible not to be (fr. 6, 8-9; fr. 7, 1-2). Against this interpretation $O^{\prime} B$ Brien has forcefully argued at length that Parmenides never relaxes a strict logical distinction between being and nonbeing, so that the two are mutually exclusive (1987, 187-226). O'Brien suggests that Owen erred in anachronistically importing into his interpretation of Parmenides the Aristotelian laws concerning the contradictories of modal propositions $(1987,192-6)$. He argues that Parmenides must be committed to a logical scheme according to which a proposition is necessary if and only if it is possible (1987, 288-94). $\mathrm{O}^{\prime}$ Brien rightly sees that Parmenides is ultimately committed to identifying 
menides not to have addressed this possibility. Let us imagine the goddess arguing from the principle that what is thinkable is a possible being ${ }^{17}$ to the conclusion that what is thinkable is a being. In this context we read fr. 6.1-2 (following the manuscript for 6.1), which I translate: 'it is necessary to say and to think what is for being, for it is for being, but it is not nothing. ${ }^{18}$ I command you to ponder these things.' This can be interpreted as follows.

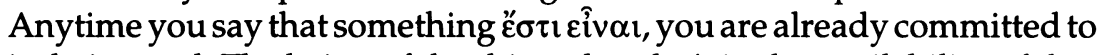
its being real. The being of the thing already is in the availability of that being. ${ }^{19}$ So the thing itself already is. ${ }^{20}$ You are not speaking of $\mu \eta \delta$ '́v; your speech is not without object. It is perhaps in regard in such items that, in fr. 4, 1 Parmenides declares 'see those things, though they are away from

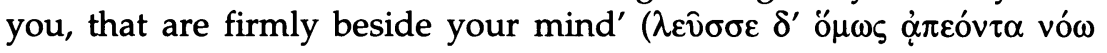

possible and necessary being. I differ in proposing that fr. 6 can be read as an argument for the thesis that every possible being is a being, and that the identification of every being as a necessary being follows from the thesis of the homogeneity of being posited at fr. 8, 22-5. If we are to follow $\mathrm{O}^{\prime}$ Brien in denying that such an argument is present, we must either consider Parmenides a shoddy thinker or follow O'Brien in considering the Aristotelian conception of possibility as wholly inapplicable to everyday pre-Aristotelian discourse. Both options ought to be avoided if possible.

17 'Being' here can be interpreted as either 'existent,' 'predicate,' or 'fact.' See n. 1.

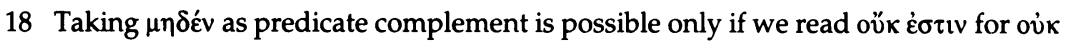

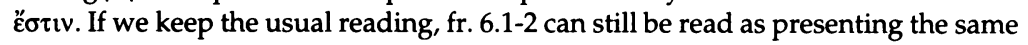
argument. For in that case we can render the first half of fr. 6.2 as it is not possible for nothing to be', understood as 'the being of nothing has no status of availability at all.' Cf. O'Brien (1987, 27, 214n19). It would follow that the notion of a possible that is yet unreal (i.e. nothing) is incoherent; insofar as a possible entity has the status of being available for being, it is not nothing.

19 Robinson $(1975,627)$ likewise takes ćóv to have a "locative" or "availability" use' here. For an alternative account, see n. 10.

20 Robinson $(1975,627-8)$ similarly translates the second half of 6.1 'for it is there to be real,' though he understands the argument of 6.1-2 very differently, resting on the (to my mind unjustified) assumption that what is real is either what is available for

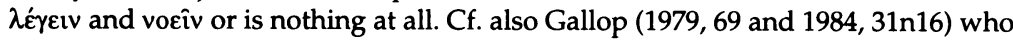
interprets 6.1 as to the effect that 'what is there to speak and think of is there to exist.' Gallop recognizes the philosophical importance of the locative overtones of the existential ह̌ $\sigma \tau$. I differ from Gallop insofar as, following Kahn, I take it to be the

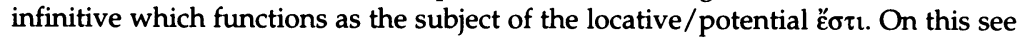
Cordero (1979, 3-4) and Stokes (1971, 306n44). 
$\left.\pi \alpha \rho \varepsilon o ́ v \tau \alpha \beta \varepsilon \beta \alpha{ }^{\prime} \omega \varsigma\right)$. A being that is merely a possible being still has a being which, though in some sense apart from (ơ⿱ $\alpha_{0}$ ó) us, still is, and it is through our minds that we are aware of this. ${ }^{21}$

Tugwell was right in denying a sharp distinction for Parmenides between the potential kiv $\alpha$ l on the one hand, and the existential (or veridical or copulative) Eiv $\alpha$ l on the other. But this is not a cause of conceptual confusion, leading to a bad argument. ${ }^{22}$ Instead, we see that Parmenides has explicitly considered the status of a possible existent; its being is, as an availability, intention or goal. Though Parmenides' thinking is led by the linguistic idiom in which he works, his thought is not bound to it. Parmenides recognizes that any status given to a possible entity grants to it some kind of being. At this stage in the argument, that is all he needs to secure the conclusion that any possible object of thought or reference already is. He has not yet argued that there cannot be different modes of being. That must wait until fr. 8, 22-5, ${ }^{23}$ in which, on the prevailing interpretation, Parmenides affirms the homogeneity and continuity of being. Those who, like myself, accept the traditional interpretation of Parmenides as a monist, find the argument for the unity of being within these lines. ${ }^{24}$

Whatever we think of this argument for monism (if indeed it is Parmenides' argument) need not color our evaluation of the argument for the existence of possible beings that we are presently considering. This argument is that, as soon as we take possibilities to be real features of the world, some ontological status must be granted to a possible being.

At this point it would be useful to contrast the argument for the being of the object of thought and speech that I am attributing to Parmenides with the Meinongian argument for the being of unreal objects. ${ }^{25}$ On

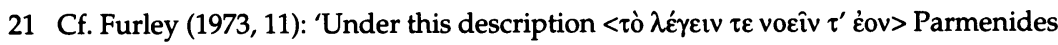
says that it must be, because it can be.'

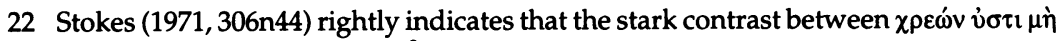

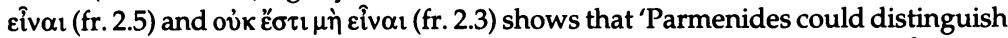
in use, if not in the abstract' between the potential and existential uses of Eiv $\alpha$.

23 Furth $(1968,121)$ sees the argument against merely possible objects as implicit in fr.

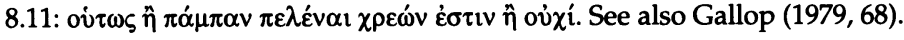

24 See e.g. Owen (1987a, 12-13), Hussey (1972, 92-3); against this see Mourelatos (1970, 111-14), Barnes $(1979,7-12)$ and Curd (1991, 256-7). 
Meinong's account, we must ascribe being (sein) to a square circle or a mountain of gold, for they already have the ontological status of being objects of thought, even though they are not real (wirklich). For to be an object of thought is to already have the status of being an object. Such a status is to be granted to that for which it is impossible to be real, as well as to that whose reality is possible, but absent (Meinong 1960,76-86). On this account, it is the thinkability of a thing which directly grants to it its being. Parmenides' argument differs in two important respects. First, in fr. 3 Parmenides takes it as axiomatic that only what is possibly real can be an object of thought. So he would on the face of it deny that a square circle is thinkable. Second, he takes the fact that we can think of a thing to be evidence for its having the status of being possibly real. He then argues that a possible reality must already in some sense be. This is an immediate consequence of its possibility, not of its thinkability, as for Meinong.

There is a long and distinguished history to the argument that a possible being must already be by virtue of its possibility. I indicate only three examples, one drawn from ancient philosophy (Aristotle), and two from contemporary analytic metaphysics (Quine and Lewis), in order to indicate the importance of the insight I attribute to Parmenides and how it has been employed for very different ends.

For Aristotle as well as Parmenides, a potential being is a being, albeit a being of kind very different from that of an actual being. Aristotle was led to posit potentiality as a kind of being for fundamentally Parmenidean reasons. On several occasions, Aristotle addresses the Parmenidean challenge to the possibility of change: how can what is come from what is not? (fr. 8,9-10) He never responds by denying that it is impossible for what is to come to be from what is not at all ( $\dot{\alpha} \pi \lambda \hat{\omega} s)$; rather the problem is to be solved by distinguishing different modes of being and nonbeing. Parmenides is said to have erred in not having distinguished between potential and actual being; an attribute, activity, or substance must already potentially be in the persistent substrate from which it comes to be (Phys I 8, 191b28-9, GCI3,317a32-b33, cf. Metaph Ө3, 1046b29-1047a29.) We see that from an Aristotelian point of view, there is nothing amiss in the

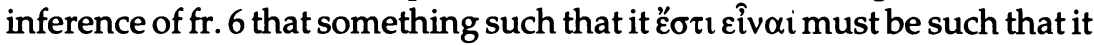

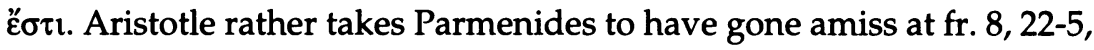
where it is argued that all being is homogeneous. 
Aristotle has no qualms in positing an infinite and in principle unspecifiable set of possibilities that are ontologically grounded as inherent in actual substances. (Indeed, potential beings alone are the sort of being of which there can be an indefinite quantity. This is a consequence of Aristotle's view that quantitative infinity is entailed by the possibility of always making one more division of a magnitude, and hence exists only in potentiality; Phys III 7, 207b1-15.) These are things or features of reality that are, in potentiality. A potentiality will not be able to do its work for Aristotle unless it is a potential being, where this means not simply a potentiality for being, but something that already is a being, in the manner of a potentiality. Thus at Metaph $\Delta 7,1017 \mathrm{a} 35-\mathrm{b} 9$, Aristotle distinguishes potentiality and actuality as modes of being: 'Further eiv $\alpha$ s signifies potential being and actual being, in the cases of the things we have discussed. For we say that both the one potentially seeing and the once

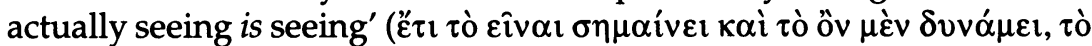

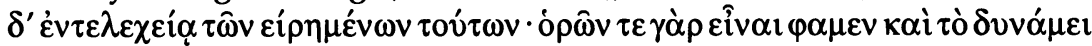

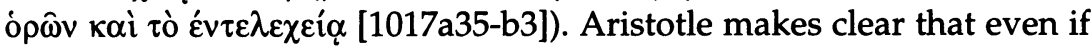
something has no actual being, as long as it can have actual being, it can already be said to be, for it is in potentiality. This is a metaphysical claim about the modes of being, not merely a remark about linguistic usage. Aristotle would thus accept the argument of fr. 6, 1-2 of Parmenides' poem, as I have reconstructed it, though he would resist the further inference that all being, including both possible being and actual being, is homogenous.

Quine also accepts the Parmenidean insight that a possible being is already a being. ${ }^{26} \mathrm{On}$ this basis Quine argues that any possible beings to which we can refer must be such as can be quantified over and individuated like any other being. The problems involved in such individuation and quantification (Quine 1961, 2-4), which were of no concern to Aristotle, lead Quine to hold the view that there are in truth no possible entities. If a semantic analysis is to be given of modal propositions, it will not be through appeal to possible beings. So Quine is in agreement with Parmenides and Aristotle that a possible entity (if there were such a thing) would have to be regarded as a being, with a place in one's ontology. He also agrees with Aristotle that possible and actual being 
are not to be identified. But he disagrees with Aristotle insofar as he denies that there are, in fact, any merely possible beings.

Parmenides never clearly specifies exactly what sort of thing counts as a being. On the standard reading of the poem (which I accept), by the end of his metaphysical deduction, only a single, partless changeless being is left as object of reference and thought. Aristotle, who rejects Parmenides' metaphysical deduction, takes there to be as many kinds of possible beings as there are actual beings. The doctrine of the categories is meant to account for the ways in which we say that a thing is, and consequently, to account for the ways in which something really is. Quine too takes possibilia (if there were such things) to be of the same kinds as the sorts of beings referred to in nonmodal discourse; thus his example of the 'possible man in the doorway' $(1961,4)$. Lewis too is concerned with the status of possible subjects and predicates of the kind that are the objects of nonmodal discourse. But, like many contemporary philosophers, he champions possible worlds semantics as providing a means by which one can individuate and quantify over these possible entities. The metaphysical problem of the ontological status of possibilia is not thereby solved. But in this case the focus is on a certain kind of entity, a world, with its own history and inventory of inhabitants. Lewis's argument for 'modal realism' in regard to possible worlds (and, derivatively, in regard to the inhabitants of possible worlds) again follows essentially Parmenidean lines: we posit possible worlds as beings (albeit possible beings). Hence possible worlds exist just as much as does the world in which we find ourselves. As Lewis $(1986,2)$ writes 'I do not have the slightest idea what a difference in manner of existing is supposed to be.' The only difference between the 'actual' world and possible worlds is perspectival: 'Every world is actual at itself, and thereby all worlds are at a par. That is not to say that all worlds are actual - there's no world at which that is true' (Lewis, $1986,93)$. When one speaks of the 'actual world' one speaks of that world, whichever it is, of which the speaker is an inhabitant.

So Lewis agrees with Parmenides, Aristotle, and Quine that a possible being (if there is such a thing) is a being. He agrees with Aristotle and Quine that possible being and actual being are not identical. He agrees with Quine that the problems concerning individuation of and quantification over possible entities are severe enough to warrant rejection of the Aristotelian view that there are an infinite and unspecifiable number of potential beings. But, unlike Quine, he believes these problems can be solved through possible worlds semantics.

As in so many other respects, Parmenides is seen to have fixed on a crucial metaphysical point to which later thinkers are indebted, whether 
the debt is recognized or not. Although they differ in the extent to which they are willing to grant that difference in the modes or kinds of being is intelligible, all four philosophers accept that a thing either is or is not; there is no middle ground. Like Parmenides, we can only conceive of a possible being as having some kind of status of availability, which involves a kind of being, even if this status is not the same as that granted to things we call real or actual.

Let us return to where we began: Parmenides' argument for the thesis that only what is can be an object of reference or thought. Parmenides asserts without argument that whatever can be thought can be. He argues that what is not cannot be, not, as Owen suggests, through a misplacement of the modal qualifier ${ }^{27}$ nor, as Tugwell suggests, through being led astray by the fact that eivol is equivocal, but on the basis of a reductio ad absurdum argument: If we assume that the nonbeing can be, then it already has the status of something whose being is present insofar as it is available. As such, it is, which contradicts the premise that it is not. Hence no nonbeing can be an object of thought; if something is an object of thought, it is a being.

In this way Parmenides has a respectable argument in support of the goddess's admonition to pursue only the first way. Because Parmenides has not yet asserted that all being is homogenous, the argument does not yet commit Parmenides to the view that there is no distinction between possible and actual being (which, if we follow Aristotle (Metaph $\Delta 12$, $1019 \mathrm{~b} 27-35$ ) in defining the possible as that of which the contradictory is not necessary is tantamount to the view that all being is necessary being).

An objection can be raised: fr. 2, in which Parmenides does present his conclusions, does apparently assert that what is necessarily is (ovk

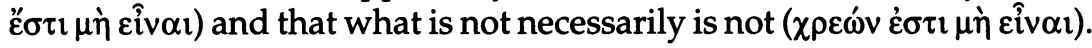
We cannot take this conclusion as dependent on the argument of fr. 8, 22-5, since the deductions of fr. 8 rest on the necessity to adhere to the first way and reject the second way, which is what fr. 2 asserts. Is

27 Cf. Robinson $(1975,633)$ : 'The interpretation of 6.1-2 offered in this paper absolves Parmenides of any supposed 'modal fallacy,' since the problems involved in a 'de $r e$ interpretation of a modal statement' ... are not in fact in question; Parmenides is discussing availability, not possibility.' I differ in taking Parmenides to begin by discussing possibility, but then to support his argument by giving an account of possibility as availability. 
Parmenides again to be charged with a modal fallacy? Are we to say that

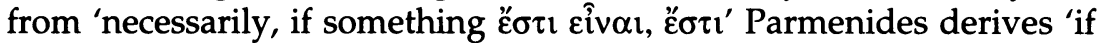

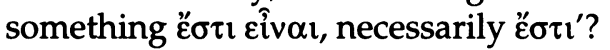

I think not. Though the thesis of the homogeneity of being does commit Parmenides to the identity of being and necessary being, and likewise to that of nonbeing and necessary nonbeing, there is no need to take Parmenides to be asserting this in fr. 2. The modal qualifiershere could simply be taken to indicate logical necessity: if something is it necessarily follows that it is; if something is not it necessarily follows that it is not. ${ }^{28}$ Parmenides' argument in support of taking the first way of inquiry and rejecting the second, as he expresses it, is neither fallacious nor circular. ${ }^{29}$

Unlike Parmenides' first way, the interpretive path I have here indicated is only one of many. And, while Parmenides takes being to be homogeneous, interpretations of a text will not be homogeneous in their advantages. While Parmenides' goddess offers strict orders for thought, this paper is an invitation to explore only one among many paths for thinking about Parmenides' poem. ${ }^{30}$

Department of Philosophy

Coughlin Hall 132

Marquette University Milwaukee, WI 53233

USA

28 See Gallop $(1979,78 \mathrm{n} 37)$.

29 Still, fr. 5, whatever else it means, apparently indicates that the earlier parts of the poem can be read and understood in the light of the later parts. So it is possible that fr. 2 is purposefully equivocal. If this is so, fr. 2 does not only assert that the being of what is and the nonbeing of what is not are deduced as a matter of logical necessity; it also asserts the de re necessity of the being of what is and the nonbeing of what is not, which is to be argued for on the basis of fr. 8's thesis of the homogeneity of being.

30 I would like to thank two anonymous referees for this journal, for their valuable comments on an earlier draft. 


\section{Owen Goldin}

\section{Bibliography}

Anscombe, G. E. 1968/9. 'Parmenides, Mystery, and Contradiction'. Proceedings of the Aristotelian Society 69 125-32.

Barnes, J. 1979. 'Parmenides and the Eleatic One'. Archiv Für Geschichte Der Philosophie 61 1-21.

Barnes, J. 1982. The Presocratic Philosophers. London: Routledge and Kegan Paul.

Burnet, J. Early Greek Philosophy. 4th. ed. London: Macmillan.

Cordero, N. L. 1979. 'Les deux chemins de Parménide dans les fragments 6 et 7 '. Phronesis 24 1-32.

Cordero, N. L. 1987. 'L'histoire du texte de Parménide'. in P. Aubenque, ed., Études sur Parménide. Paris: J. Vrin, vol. 2, 3-24.

Curd, P. K., 1991. 'Parmenidean Monism'. Phronesis 36 241-264.

Furley, D. J. 1973. 'Notes on Parmenides'. in E. N. Lee, A. P. D. Mourelatos, and R. M. Rorty eds., Exegesis and Argument: Studies in Greek Philosophy Presented to Gregory Vlastos, Phronesis suppl. vol. 1. Assen and New York: Van Gorcum and Humanities Press, $1-15$.

Furth, M. 1968. 'Elements of Eleatic Ontology'. Journal of the History of Philosophy 6: 111-32, repr. in A.P. D. Mourelatos, ed., The Pre-Socratics: A Collection of Critical Essays. Garden City, N. Y.: Doubleday, 1974, 241-70.

Gallop, D. 1979. 'Is or Is Not?' The Monist 62 61-80.

Gallop, D. 1984. Parmenides of Elea: Fragments: A Text and Translation with an Introduction. Toronto: University of Toronto Press.

Hussey, E. 1972. The Pre-Socratics. New York: Charles Scribner's Sons.

Kahn, C. 1966. 'The Greek Verb "To Be" and the Concept of Being'. Foundations of Language 2 245-65.

Kahn, C. 1968/9. 'The Thesis of Parmenides'. Review of Metaphysics 22 700-24.

Kahn, C. 1973. The Verb Be in Ancient Greek. Dordrecht: Reidel.

Lewis, D. 1986. On the Plurality of Worlds. Oxford: Basil Blackwell.

Mansfeld, J. 1964. Die Offenbarung des Parmenides und die Menschliche Welt. Assen: Van Gorcum.

Meinong, A. 1960. 'The Theory of Objects', tr. I. Levi, D. B. Terrell and R. M. Chisholm, in R. M. Chisholm, ed., Realism and the Background of Phenomenology. Glencoe, Il.: The Free Press, 76-117.

Mourelatos, A. P. D. 1970. The Route of Parmenides. New Haven: Yale University Press.

Mourelatos, A. P. D. 1979. 'Some Alternatives in Interpreting Parmenides'. The Monist 62 3-14. 
O'Brien, D. 1987. 'Le Poème de Parménide: Texte et Traduction', in P. Aubenque ed., Études sur Parménide. Paris: J. Vrin, vol. 1, 1-324.

Owen, G. E. L. 1987a. 'Eleatic Questions'. Classical Quarterly, N.S. 10 (1960), 84-102; repr. in R. E. Allen and D. J. Furley, eds., Studies in Presocratic Philosophy, Vol. II: Eleatics and Pluralists. London: Routledge and Kegan Paul, 1975: 48-81 and in M. C. Nussbaum, ed., Logic, Science and Dialectic. Ithaca: Cornell University Press, 1987, 3-26, to which I make reference.

Owen, G. E. L. 1987b. 'Plato and Parmenides on the Timeless Present'. The Monist 50 (1966), 317-40; repr. in A. P. D. Mourelatos, ed. The Pre-Socratics. Garden City, N. Y.: Doubleday, 1974: 271-292 and in M. C. Nussbaum, ed., Logic, Science and Dialectic. Ithaca: Cornell University Press, 1987, 27-44, to which I make reference.

Quine, W. V. O. 1961. From a Logical Point of View, 2nd. ed., rev. Cambridge, Mass.: Harvard University Press.

Robinson, T. M. 1975. 'Parmenides on the Ascertainment of the Real'. Canadian Journal of Philosophy 4 623-33.

Sorabji, R. 1980. Necessity, Cause, and Blame: Perspectives on Aristotle's Theory. Ithaca: Cornell University Press.

Stokes, M. C. 1971. One and Many in Presocratic Philosophy. Washington D.C.: Center for Hellenic Studies.

Tugwell, S. 1964. 'The Way of Truth'. Classical Quarterly ns. 14 36-41. 